\title{
CLEAN AND HEALTHY LIVING BEHAVIOR EDUCATION ON SCHOOL AGE CHILDREN AND MOTHERS IN THE LOCAL COMMUNITY OF BANTAR GEBANG
}

\author{
Wardina HUMAYRAH* and Megah STEFANI \\ Nutrition Study Program, Food Technology and Health Faculty, Sahid University \\ *wardina_humayrah@usahid.ac.id
}

\begin{abstract}
The BGBJ is commonly known as "Biji-Biji Bantar Gebang" which is precisely located in Bantar Gebang where was collected 7000 tons of Jakarta's waste in final dumped. The BGBJ is a unique community asset that functions as both a hostel and others, a place that caters to both visitors and the local community. The BGBJ community has limitations for training on Clean and Healthy Life Behavior (CHLB) for school-age children. So that this community service proposal was made with the aim of holding a collaboration on a CHLB program for mothers and children in the environment around the Bantar Gebang TPST between extension workers and the BGBJ community. The activity method was include: problem mapping, morning exercises, pre-post test of CHBL education, singing hand-washing chants, role play washing hands with soap and water, and evaluation. The results show that the pre- and post-test on the activities of understanding CHLB's scores of 90.35 and 92.11, respectively. The understanding of CHLB among participants was good before the program was held, this is from the results of the pre-test which were also quite high. This shows that PHBS educational activities are also meaningful to increase participants' understanding. Furthermore, it is hoped that all participants can apply this understanding in their daily lives.
\end{abstract}

Keywords: Bantar Gebang, behavior, clean, healthy, mothers, school-age children

\section{BACKGROUND}

Most of the residents of Bantar Gebang are in the middle to lower economic class. Based on data from the local community of Bantar Gebang Seeds (BGBJ) it shows that there are around 3000 families living around the Bantar Gebang TPST, who work as scavengers. Children in Bantar Gebang generally do not get a proper education.

The pungent smell caused by waste pollution around the landfill does not only affect the health but also the mental condition of the residents of Bantar Gebang. Many of the residents are less confident when they have to appear in social circles outside Bantar Gebang, one of which is because of the unpleasant smell attached to the residents' clothes. Carrying a mission to give dreams to children in the Bantar Gebang area, the local community, BGBJ, is present as an educational forum and one of the liaisons for the residents of Bantar Gebang with the outside world.

BGBJ is commonly known as "Biji-Biji Bantar Gebang" which is precisely located in Bantar Gebang. Every day, 7000 tons of Jakarta's waste is dumped in the Bantar Gebang TPA. BGBJ caters to low-income families salvaging valuables from this waste, such as plastic, paper, metal, glass, and trash. BGBJ is a unique community asset that functions as both a hostel and others, a place that caters to both visitors and the local community. The originator of BGBJ, Resa Boenard, was born and raised in Bantar Gebang.

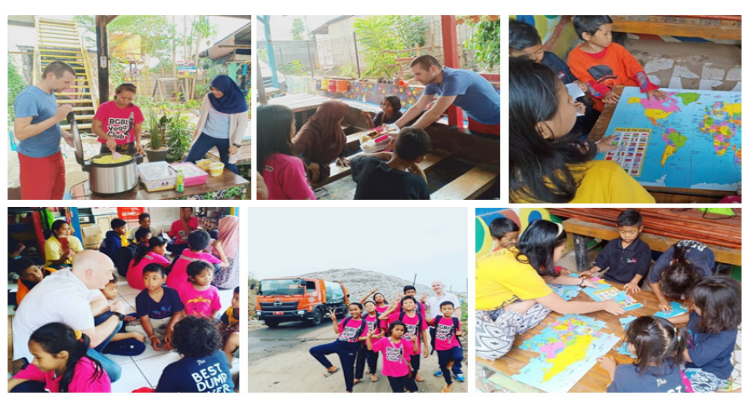

Figure 1 The BGBJ Community's Activities
This community faces a number of daily challenges at the landfill. These include poor quality housing, lack of sanitation, work-related injuries and illnesses, and an unpleasant living environment. According to the results of recording the density level of flies carried out by the environmental sanitation section of the Bekasi Health Office (2004) in the Bantar Gebang TPA Bekasi and surrounding areas, it is very dense. The average measurements were carried out, such as at a distance of 100 meters from the TPA entrance office totaling 22.6 fish/grill, settlements in RT 04/04 Sumur Batu sub-district amounted to $18.6 \mathrm{fish} / \mathrm{grill}$ and scavenger settlements amounted to 31.4 fish/grill (Wijayanti 2009).

BGBJ provides education, training, assistance, food and fun for children who do not have access to these resources. Through education and skills training, this community aims to provide an alternative for young people by providing tools and knowledge to break the cycle of poverty and create a healthy and safe environment for themselves and their families. The local BGBJ community runs a number of activities and projects. Every Sunday they run classes in various topics, such as English, IT, music and art for teenagers in the neighborhood of TPST Bantar Gebang.

On the other hand, the BGBJ community has limitations for training on Clean and Healthy Life Behavior (CHLB) for school-age children and mothers. So that this community service proposal was made with the aim of holding a collaboration on a Clean and Healthy Life Behavior Education program for mothers and children in the environment around the Bantar Gebang TPST between extension workers and the BGBJ community.

The emergence of diseases due to an unsupportive environment, most often caused by an unhygienic and unhealthy environment. This vulnerable environment will definitely have an impact on children becoming more susceptible to disease. Bantar Gebang is one of the areas 
that are vulnerable to being exposed to disease and the most frequently attacked targets are children. This is due to the children's playing environment around Bantar Gebang which is exposed to various kinds of pollution. Therefore, a Clean and Healthy Life Behavior Education program is needed in order to reduce and reduce the risk of exposure to disease in children in the area, so that there is a change in the health status of children that is more optimal.

The Clean and Healthy Life Behavior Program (CHLB) is a form of embodiment to provide learning experiences or create a conducive condition for individuals, families, groups and communities to increase knowledge, attitudes and behavior in order to apply healthy ways of living in order to maintain, maintain, and improve health (Gani HA et al. 2015). This program is very suitable and appropriate to be implemented in the Bantar Gebang Waste-Dump area.

\section{METHODS}

This community service program aims to increase the awareness of housewives and children to wash their hands with soap and running water, especially during three important moments and to do the five steps of washing hands with soap and running water appropriately, so that the children home can imitate clean and healthy attitudes and behaviors. The achievement of changes in attitudes and behavior is carried out in several form, including:

1. Problem mapping. At this stage a mapping of the problems faced by the BGBJ community was carried out through joint discussions with the community founders, the question and answer process was carried out in depth accompanied by direct assessment by the implementers during the field survey.

2. Morning exercises. Housewives and children along with the implementers do sports together first so that a sense of belonging is formed so that it is hoped that the education provided will be successful and can be carried out in a sustainable manner.

3. Pre-test. Housewives and implementers chat in two directions about the habit of washing hands at home, how the concept of healthy and clean according to the mother briefly to find out the understanding of knowledge about healthy lifestyles for mothers and families.

4. Role play to hand washing with soap and water. The material for hand washing with soap was delivered through emo-demo and role-playing methods. Mothers and children are asked to be involved in role-playing about the concept of germs that will move into the body if they are not diligent in washing their hands at three important moments, namely before preparing food, before breastfeeding and after cleaning the child.

5. Singing hand-washing chants. The executor provides an educational process in the form of singing handwashing slogans so that it is easier for housewives and their children to understand. The chants were carried out together using audio-visual guided by the executor, it is hoped that the proper hand washing steps can be recorded by both the mother and child.

6. Post-test. The post-test was conducted to determine the success of the educational process for hand washing with soap

7. Evaluation. In an effort to sustain this program, the implementer asked the founders of the BGBJ community to promote the hand washing program with soap supported by the provision of hand soap and clean cloths for mothers to use in their respective homes.

The implementation of nutrition education programs regarding a clean and healthy lifestyle, namely hand washing with soap is carried out through several stages as follows:

1. Audience with the BGBJ community. Conducting discussions with the founders of the BGBJ community and direct observations of the community environment during visits and field surveys. Drawing conclusions on the state of the community based on joint discussions, so that the right solution is formed to solve the problems that occur.

2. Preparation of activity plans.Prepare field activity plans based on program objectives, visit locations and get acquainted with residents around the BGBJ community, calculate operational cost budgets, determine success indicators so that they can be evaluated and the monitoring process post-program implementation.

3. Implementation of activities. The activities are carried out by preparing field facilities, preparing appropriate emo-demo educational materials for the delivery of nutrition education, implementing role-playing and making chants as supporting materials for children and housewives.

4. Monitoring and report generation. The monitoring process was carried out by the founders of the BGBJ community through the sustainability of the hand washing program with soap at their respective mothers' homes. As the executor, support for the provision of free hand soap and clean hand wipes for mothers is expected to improve hand washing attitudes and behavior in their respective homes.

\section{RESULTS AND DISCUSSION}

The number of participants who attended was 26 people from the target of 30 people $(87 \%)$. Attendance that did not reach $100 \%$ was thought to be caused by the busyness of mothers and children on Sundays which coincided with the implementation of the activities. Direct evaluation was carried out on the results of the pre-test and post-test on the activities of understanding scores of 90.35 and 92.11, respectively. The understanding of Clean and Healthy Living Behavior (CHLB) among participants was very good before the program was held, this is from the results of the pre-test which were also quite high. There were 3 people whose pre-test scores were quite low but 
increased after the activity with an increase in scores of 1650. This shows that CHLB educational activities are also meaningful to increase participants' understanding.

Furthermore, it is hoped that all participants can apply this understanding in their daily lives and also disseminate it to mothers or other children who are unable to attend the activity. The BGBJ community is committed to continuing to provide CHLB education every weekend so that it can change the behavior and attitudes of the surrounding community for the better regarding PHBS practices. In the future, similar activities can be further promoted but it is necessary to measure a deeper understanding of daily habits related to CHLB.

\section{Audience with the BGBJ Community}

Prior to the implementation of the community service team, internal coordination was carried out to prepare for the meeting time with the founders of the BGBJ Community. Hearings were conducted with the BGBJ Community first to explore the needs and planning of program activities. This hearing was conducted to explore problems so that they can provide solutions according to the needs of the community and reach an agreement regarding cooperation in the CHLB education program with the BGBJ community. The founder of the BGBJ community is an environmental activist who regularly holds activities for children who collect garbage around the Bantar Gebang TPST environment.

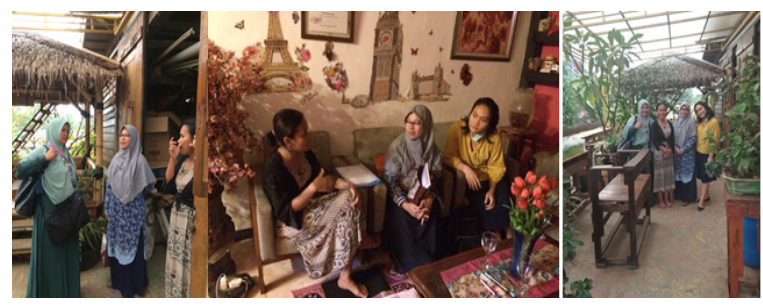

Figure 2. Audience with the Founder of the BGBJ Community (Black Cardigan)

The meeting resulted in an agreement regarding the location, time and participants of the activity. The agreement on the implementation of the program was reached through a discussion process with the founders of the BGBJ community with an approach to gymnastics with Housewives and School Age Children before the implementation of the CHLB education program at the BGBJ basecamp. The schedule begins with morning healthy exercise and continues with CHLB with role play. Furthermore, the program implementation activities were socialized by this community by inviting several housewives with their children around the community environment.

\section{The process of providing education}

The activity started with morning exercise together starts at. 09.00 which was led by a member of the community service team and also a team from the BGBJ community, followed by 6 housewives and 15 children around BGBJ. Then, the education of CHLB is carried out using the emo-demo method, namely the healthy rumpi demo. This demo is intended for housewives to learn the importance of washing hands with soap and running water, especially at 3 important moments, and mothers learning about 5 steps to wash hands with soap and running water properly.

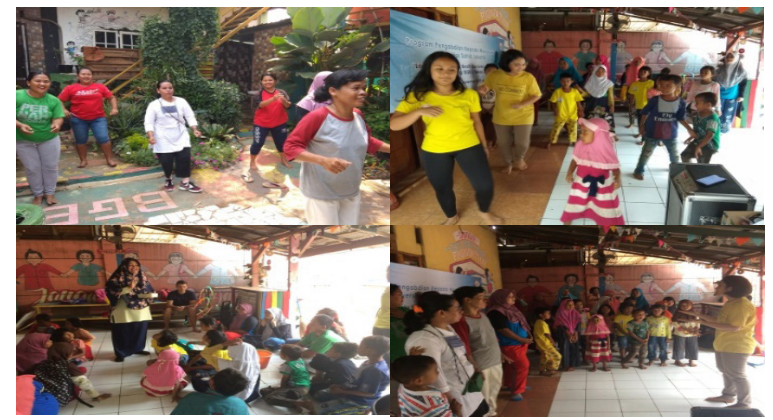

Figure 3 Morning exercise and education of CHLB

The process of implementing the role playing demo

Role playing is carried out by housewives to practice emo-demonstrations regarding hand washing. Through role-playing, it is hoped that the mother will be able to appreciate the desired character, the success of the mother in living that role will determine whether the process of understanding, appreciation and self-identification of values develops.

The role-playing scenario: two mothers are asked to bring a broom, then the broom's arm is smeared with oil. As the picture of the scenario when the mother sweeps, it is certain that her hands will also be greasy. Then with oily hands, the mother was asked to feed her child to eat. What will mother do? Is it okay to feed a child without washing their hands? Or choose to wash your hands first before feeding your child? The analogy of the role-play is that if oil is a germ, then germs enter the child's mouth when the mother feeds her without washing her hands, so that the child is more at risk of various diseases. With an emotional touch in the demonstration to mothers, it is hoped that the education will be successful in implementing it in everyday life.
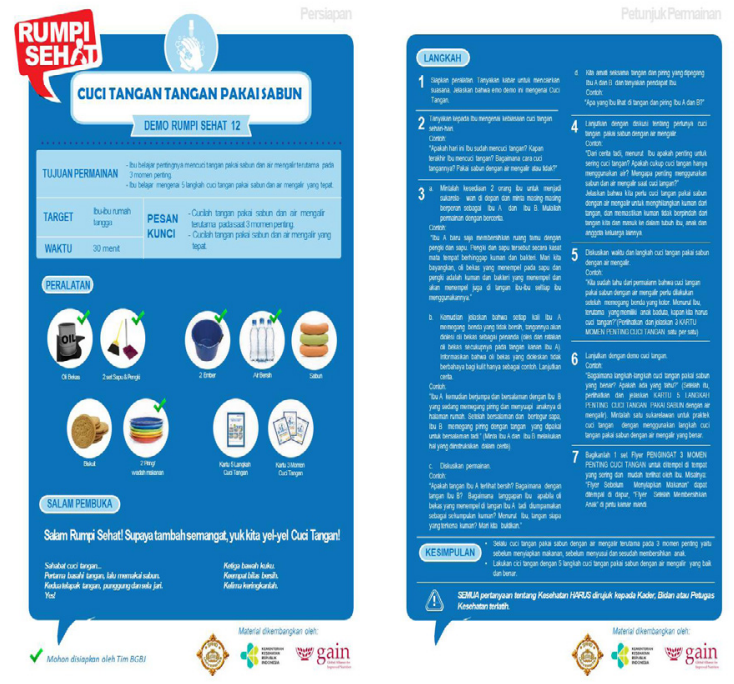

Figure 4 The role play materials for CHLB education 


\section{CONCLUSION}

The activities went well, achieved the awareness of CHLB by the participants. Increased understanding of CHLB among participants has been very good. However, there still need further sustainable program monitoring to be carried out to ensure there is a change in attitude related to CHLB in daily habits.

\section{ACKNOWLEDGEMENT}

First and foremost, praises and thanks to the God, the Almighty, for His showers of blessings throughout this program work to complete the research successfully. We would like to express the gratitude to Research and Community Service Institution, Sahid University, for giving the grant funding to do this program achieved. We also thanks for leader of BGBJ Resa Boenard and the society surround Bantar Gebang, Bekasi for the warm acceptances and good cooperation through this program came true.

\section{REFERENCES}

Boenard Resa. 2019. Seputar Kerajaan BGBJ. Wawancara langsung 12 Agustus 2019, Komunitas Kerajaan BGBJ, Bantar Gebang, Bekasi, Jawa Barat
Gani HA et al. 2015. Perilaku Hidup Bersih dan Sehat (PHBS) pada Tatanan Rumah Tangga Masyarakat USING (Studi Kualitatif di Desa Kemiren, Kecamatan Glagah, Kabupaten Banyuwangi). Jurnal IKESMA Volume 11 Nomor 1.

Mulyadi Didi. 2016. Mengembangkan kepedulian akan pentingnya pendidikan untuk meningkatkan kesejahteraan masyarakat pemulung di tpa bantar gebang. Prosiding

Seminar Nasional dan Gelar Produk UMM, tanggal 17-18 Oktober 2016.

Sitio Raston. 2017. Pengaruh Jumlah Sampah Masuk Bantargebang terhadap Biaya Kesehatan Masyarakat Ciketingudik dan Sumurbatu. Jurnal Aplikasi Manajemen, Ekonomi dan Bisnis, Vol. 2 (1), Oktober 2017, ISSN 2541-1438; E-ISSN 2550-0783, diterbitkan oleh STIM Lasharan Jaya.

Wijayanti PD. 2009. Hubungan kepadatan lalat dengan kejadian diare pada balita yang bermukim sekitar Tempat Pembuangan Akhir (TPA) Sampah Bantar Gebang. Universitas Indonesia: Depok. 